
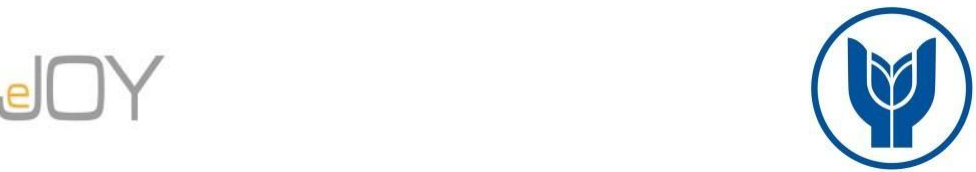

Şen, Ö., Akel, G. / Journal of Yasar University, 2021, 16/62, 524-547

\title{
Where Does Golf Tourism Go? Yesterday, Today, Tomorrow
}

\section{Golf Turizmi Nereden Nereye Gidiyor? Dün, Bugün, Yarın}

\author{
Özlem ŞEN, Antalya AKEV University, Turkey, ozlem.sen@akev.edu.tr \\ Orcid No: 0000-0001-6506-170X \\ Gökhan AKEL, Antalya AKEV University, Turkey, gokhan.akel@akev.edu.tr \\ Orcid No: 0000-0003-4996-1796
}

\begin{abstract}
The increase in the importance and popularity of sports tourism has led to both a sectoral development and an increase in academic studies. Golf tourism is only one of many branches in the sports tourism category. In this study, 46 studies on golf tourism published in the Web of Science (WoS) database were examined bibliometrically. This study stands out in the literature due to the lack of a bibliometric study in the field of Golf Tourism. With the evaluation of golf tourism studies, we aim to reveal the changes and trends in this field in the last 36 years. Articles published between 1983 and 2020 in the "golf tourism" topic of the WoS database were searched, and the data of the relevant published studies were obtained. The bibliometric scientific mapping method was used to perform the analysis using SciMAT and VOSviewer software. In this paper, the number of publications, publication types, publication languages, citation analysis, author citation numbers, journal citation network, and country collaborations was analyzed. Our research indicates that the number of publications has increased significantly since 2011, suggesting a recently-developing interest in the field. The studies were primarily scientific articles published in the English language. England played a primary role in the country collaborations among authors. Turkey contributed three publications to the literature. The analysis found that the journal with the highest number of citations is Tourism Management. The authors with the highest number of citations were Barros, C., Butler, R., Correia, A. The published studies on the subject of Golf Tourism have strong ties with the themes of "Tourism", "Marketing", "Behavior", "Sustainability" and "Destination". It is thus concluded that future studies should be conducted on the relationship of golf tourism with the subject of "Management".
\end{abstract}

Keywords: Golf Tourism, Bibliometric Analysis, SciMAT, VOSviewer

JEL Classification: L83, L89, C19

Öz: Turizm gelirlerinde spor turizminin son yıllarda giderek daha önemli bir paya sahip olması bu alanda yapılan çallş̧maların sayısını da artırmıştır. Bu çalı̧̧mada spor turizmi türleri arasindan golf turizmi konusunda WoS veri tabanında yayımlanan 46 çallş̧ma bibliyometrik açıdan incelenmişstir. Golf Turizmi alanında bibliyometrik bir çalışma olmadı̆̆ gerçeğinden yola çıkılarak yapılan bu çalışma bu anlamda literatürde bir ilk olma özelliğini taşımaktadır. Bu konuda son 36 ylldaki değişikleri ve eğilimleri ortaya koymak amaçlanmıştır. Bu amaç doğrultusunda, WoS veri tabanında "golf tourism" konu başlığında ve 1998-2020 yılları arasında tarama gerçekleştirilmiş ve konu ile ilgili yayınlanmış çalışmalara ait verilere ulaşılmışstır. Analizin yapılması için bibliyometrik bilimsel haritalama yöntemi kullanılmış ve analizler SciMAT ve VOSviewer yazılımları ile gerçekleş̧irilmiştir. Çalı̧̧malar; yıllara göre yayın sayıları, yayın türleri, yayın dilleri, atıf analizleri, yazar atıf sayıları, dergi atı ağı, ̈̈̈lke iş birliktelikleri incelenmiştir. Analiz sonuçlarına göre, yayın sayıları bağlamında alana olan ilginin 2011 yllından sonra çarpıcı bir şekilde arttı̆̆ söylenebilir. Çallşmalar ağırlıklı olarak makale türünde ve İngilizce dilinde gerçekleştirilmiştir. İngiltere'nin ülke iş birlikteliklerinde kilit rol oynadı̆̆l, Türkiye'nin ise 3 yayın ile literatüre katkl sağladı̆̆ tespit edilmiştir. En fazla atı saylsına sahip derginin ise Tourism Management, yazarlarm ise Barros, C., Butler, R., Correia, A. olduğu belirlenmiştir. Söz konusu yıllarda yayınlanan çalışmalarda Golf Turizmi konusunun; "Turizm", "Pazarlama", "Davranış" "Sürdürülebilirlik" ve "Destinasyon" temaları ile güçlü bağları olduğu sonucuna ulaşılmıştır. Golf turizmi konusunun "Yönetim" konusu ile olan ilişkisine dair çalı̧̧malar yapılması gerektiği sonucuna varılmıştır.

Anahtar Kelimeler: Golf Turizmi, Bibliyometrik Analiz, ScMAT, VOSviewer

JEL Sinıflandırması: L83, L89, C19

Makale Gecmisi / Article History

Başvuru Tarihi / Date of Application Kabul Tarihi / Acceptance Date
: 22 Aralık / December 2020

: 27 Şubat / February 2021 


\section{Introduction}

Sports tourism, which has started to become a significant share of tourism revenues for many countries, has led countries to allocate more resources for research and development (Salici ve Özdaşl1, 2016; Soyak, 2013). Sports tourism is defined by Kurtzman (2005) as "using sports as a tool for tourism initiatives". The main determinant of "sports tourism" is the participation of tourists in a certain sports event. In these events, tourists can be an active participant or a passive audience.

Although golf tourism has developed in a relatively limited number of countries compared to others in the field of sports tourism, it has quickly attracted the attention of sports lovers due to the ease and attraction of travel between countries. Golf tourism has contributed to the travel and accommodation sector as a type of sports tourism, which has become increasingly attractive recently. Moreover golf tourism, in addition to other types of tourism, helps attract additional tourists and allows for the exploitation of unused land, bringing increased employment and making a country more competitive in tourism (Markwick, 2000: 516). Golf tourism has both direct and indirect effects on many sectors apart from the effects mentioned above.

The increase in the interest in golf tourism and the increase in scientific publications make it essential to examine the studies in this field. In this regard, we examined the literature with a bibliometric analysis to identify trends in the field, and to shed light on new studies to be done by identifying gaps in the literature. This study, based on bibliometric analysis, provides answers to many basic questions about publications.

This paper first reviews the literature about golf tourism and provides some sample of bibliometric researches. Then, the research method is introduced. Finally, it presents the conclusion and suggestions.

\section{Literature Review}

Golf is an outdoor sport that people of all ages can play as a leisure activity. Golf, a sport that is followed both lives from attendees to tournaments and through new media channels, has added additional tournaments in recent years due to increased interest, including being added to the Rio de Janeiro (2016) and Tokyo Olympic Games (2021). It is also regarded as the world's leading sport in terms of financial expenses (Han et al., 2016; López-Bonilla, et al., 2020; Millington, et al., 2018; Petrosillo et al., 2016). Golf has become a growing industry both with an increasing audience and an increasing number of players. It is necessary to determine the criteria that will attract golf customers and sustain their interest over the long 
term. Golf should be taken into account when determining tourism and marketing activities, because it includes rapidly-changing competitive parameters and is a high-income sport type (Hutchinson et al., 2009), which combined with the impact of globalization creates a strong opportunity for the continued growth of golf tourism. As golf tourists come from a relatively high socioeconomic level and a correspondingly high-spending market, these tourists tend to repeat. For these reasons, this market is a promising segment for a destination.

Golf tourism, which has a great popularity, can be described as a major tourism activity and is a well-developed form of sports tourism and it is the largest sports travel market. (Boukas et al., 2012, Tassiopoulos and Haydam, 2008). Since the annual growth rate in golf tourism is approximately 3 times higher than world tourism, the economic place of golf tourism in the tourism sector is very important. The fact that a golf player spends three times more than an average tourist also highlights the economic importance of golf tourism (Çetinkaya \& Dedemen, 2013; Türkiye Turizm Yatırımcıları Derneği, 2020).

Golf tourism can be described as "individuals travelling for non-commercial reasons to participate in golf activities away from the local environment" and, similar to the tourism industry in general, it is subject to increasing globalization levels (Hudson, 2003). Golf tourism, in its simplest definition, includes travels to destinations where golf opportunities are offered, either as a participant or spectator. Golf tourists are considered in three basic categories (Hudson, 2010: 3); those whose main purpose is to play golf and who travel for this purpose, those who play golf during their business trips or vacations, and participants in organized golf tournaments and similar golf events as spectators. There are many different evaluation and research areas within the scope of golf tourism in the literature. The increasing interest in sports tourism in recent years has made it necessary to carry out scientific studies. When the studies in tourism are analyzed from past to present, there are many studies, directly or indirectly related to tourism. Among these papers, it is possible to come across many bibliometric studies.

Barrios et al. (2008) analyzed 572 papers on the psychology of tourism between 19952005 in the WoS database. They provided an overview of this area and its development. In this bibliometric study, they revealed that there has been major growth in the literature and an increase in co-authoring and institutional cooperation.

Evren and Kozak (2013) examined 1217 papers published in Turkish journals between 2000-2010 in the scope of various parameters, using bibliographic analysis methods in their study, which aimed to determine the general development of tourism literature. Upon review, Anatolia: A Journal of Tourism Research has concluded that Turkey is one of the leading 
tourist journals. Also, tourism management and organization, marketing, and tourism economy of tourism between the academic community in Turkey have revealed that the most popular themes. The study also found that the most productive authors were research assistants and assistant professors, and empirical techniques were used in most of the papers.

Ruhanen et al. (2015) examined 492 articles published on sustainable tourism in 4 leading journals in tourism research between 1987-2012. Although theoretical and methodological approaches seem to mature over time, it concluded that topics and themes in sustainable tourism research remain stable, with some exceptions. However, the results have shown that there is a tendency from descriptive and conceptual studies to empirical research and studies focused on testing and applying theory.

Bozok et al (2017) researched more than 400 academic studies and revealed the features of national and international academic studies from a general perspective by making bibliometric analysis of rural tourism. Shanches et al. (2017) conducted a bibliometric study of the publication in WoS and Scopus related to wine tourism in their study. In this study, they showed the current status of scientific research by analyzing the numerical values, scope, conflicts, distribution, and concentrations of publications. In the comparative study, 238 papers and 122 different journal sets were obtained. It has been determined that WoS and Scopus databases differ in terms of content, data volume, and policies.

Jiménez-Caballero and Polo Molina (2017) examined 250 studies covering financial research in tourism between 1995-2012. In this study, they considered the tourism journals in the Scopus database. They found that the most interesting topics were financial management and corporate finance, value creation, capital structure, and investment decisions.

Garrigos-Simon et al. (2018) examined 2279 studies in the field of tourism. It was reviewed to sustainability in tourism and its relationship with both income and employment. These studies analyzed bibliometrically, showed the need to integrate the interdisciplinary nature of sustainability research in tourism, the social, economic, and environmental factors of sustainability. However, the findings indicated that research on sustainability questions had improved and had moved from more definitive and conceptual studies to applied and experimental research.

Güzeller and Çeliker (2018) aimed to determine the trends in the tourism literature bibliometrically by analyzing scientific studies conducted between 2007-2016. Furthermore, the trend between Turkey and other international publications have to identify similarities and differences. For this purpose, the top five tourism journals according to Journal Citation Reports were selected. The 4473 studies have investigated. Besides, the Turkey origin 213 
papers in tourism and hospitality journals were included in the study. According to their findings in Turkey and other international publications, experimental research is an important part of the works. Moreover, they found that organizational behaviour and management themes are the most studied and especially concepts such as perception, attitude, behaviour, intention, satisfaction, and experience were measured.

Maldonado-Erazo and Álvarez-García (2018) had bibliometrically analyzed the research in the field of thermalism, thalassotherapy, and spas in the Scopus and WoS databases. As a result of the research, it was revealed that the relevant subject had high growth potential and there was a need for information development in the sector.

Okumus et al. (2018) tested 5333 studies on food and gastronomy between 1976-2016 with bibliometric analysis. The themes that emerged with this analysis based on tourism and hotel management journals were examined. In this study, it was stated that studies increased after 2000, but there are still not sufficient studies on food and gastronomy issues.

Niñerola (2019) examined 4647 studies published in Scopus and sustainability in tourism between 1987-2018. It was concluded that the literature on sustainability matters in tourism has improved remarkably with bibliometric analysis. It also found that there were more than 300 citations in only six articles, so there were several productive authors.

Rio-Rama et al. (2019) examined 134 studies about mountain tourism, published in Scopus and WoS database. In this study, it was found that the studies on mountain tourism focus on three main research areas: climate change, sustainable development, and tourist systems.

Tregua et al. (2020) examined studies in the last 10 years on the concepts of co-creation and tourism. This study focuses on analyzing the main conceptual themes linking co-creation and tourism and identifying productive spaces for future research.

Jiménez-García et al. (2020) examined a total of 214 articles on sports tourism and sustainability in WoS indexed journals using VOSviewer and SciMAT software. It has been observed that the number of studies in this field has increased especially in the last four years.

López-Bonilla et al. (2020) examined Scopus and WoS databases based on the sustainability perspective of golf tourism research. 46 articles published in scientific journals in the last 22 years have been reviewed and identified five lines of research such as environmental impacts, environmental management, environmental attitudes and behaviors, conflicts of interest, and sustainable management and planning. 
Although the subject of golf tourism has been a significant subject over the years, there are few studies in the national and international literature showing the trends of the subject, the areas where the researchers are directed and the gaps in the field.

\section{Methodology}

Using statistics in scientific studies provides information in any field or subject in terms of scientific advancement. Situations such as the stage and level of progress can be achieved by statistical software, programs, or techniques. Therefore, the use of all statistical methods is necessary for a general inference and explanatory results. Since bibliometric analysis focuses on unknown models or samples in fields or disciplines, it is used to develop theory, to easily test hypotheses, and to evaluate and predict a field (Koseoglu et al., 2016: 191). The use of bibliometry has been well-established in academic studies from past to present and seems likely to continue to be used for many years.

Bibliometry was defined by Pritchard (1969) as "applying statistical and mathematics methods to books and other forms of written communication". Based on this definition, bibliometry can be expressed as a kind of measurement technique in which interconnected aspects of written communication can be quantified (Sengupta, 1992). The concept of bibliometry, defined as a quantitative output of previously published works (Broadus, 1987: 376). Bibliometry, which is an information and library science research area that analyzes bibliographic data such as publication year, authors, country of origin using a quantitative approach, has become very popular over the years to classify resources and develop representative summaries of leading results (Broadus, 1987; Cancino et al., 2017). According to a similar argument, bibliometric analysis is increasingly used to study the evolution of certain disciplines and map the structure and development of scientific fields (Boyack, Klavans, \& Börner, 2005). Bibliometric studies can provide useful and quick information for researchers, consultants, government officials, and managers (Koseoglu et al., 2016: 192).

Bibliometric studies have gained major attention in tourism, especially in recent years, as studies that allow the evaluation of the research quality in a particular area and the area's development (Hall, 2011: 16). When the bibliometric studies conducted in the literature are examined, national and international studies that evaluate the articles, theses, and conference papers are also frequently encountered. As the number of academic studies in a particular area increases, researchers have difficulty in finding gaps in the area. Bibliometric studies are of great importance for researchers to show the deficiencies in the literature related to the subject they want to research. Besides, bibliometric studies provide general information about authors 
and works, providing new opportunities for both academicians and managers operating in the industry.

There are some limitations as well as the benefits of bibliometric studies. For instance, only databases such as Scopus, SSCI, and WoS are used to analyze data in bibliometric studies. Since bibliometric analysis does not allow data collection from other databases, some studies are not included in the analysis. Therefore, it may not be able to present the entire frame of the field under study. These limitations need to be taken into account by the researchers for reliability and validity.

Two distinctive aspects of bibliometric mapping, which is an important research topic in the field of bibliometry, are the creation of bibliometric maps and their graphical representation. In the bibliometric literature, the most attention is paid to the creation of bibliometric maps. Also, there is a wide range of software in the literature to carry out the mapping of bibliographic data (Cobo et al., 2011). The VOSviewer program, developed to create and display bibliometric maps, can be used, for example, to create maps of authors or journals based on quotation data, or to create keyword maps based on coexistence data. The program offers a viewer that provides a detailed examination of bibliometric maps (Van Eck and Waltman, 2010).

This study aims to determine the bibliometric properties of the studies published on golf tourism and investigated in international citation indices. Research data consists of 46 studies on golf tourism published between 1983-2020 (March) and published in the WoS database. Information on the name, year, number of citations, types of publications, and publication languages of 46 studies published on "golf tourism" in this database were obtained. In citation analysis, how many sources refer to golf tourism studies, the citations received in the WoS database, and their distribution by years and publications were evaluated. The data obtained from this database related to golf tourism have been analyzed by SciMAT and VOSviewer programs.

SciMAT v1.1.04 is a Java-based program that organizes network analysis on a longitudinal level. In the program, keyword, author, citation analysis can be done and various values such as h-index and g-index total citation can be reached. According to Cobo (2012), the SciMAT program enables science mapping studies to be carried out at a longitudinal level by enabling different stages from the data loading of the science mapping workflow and the preprocessing of raw data to the visualization and interpretation of the results. Besides, the results of the strategic diagrams showing the positions of the analyzed discipline and substudy themes in the field according to density and centrality values and the weight of the 
nodes in the cluster can be obtained (Cobo et al., 2012: 1609-1630). VOSviewer v1.6.11, on the other hand, is a Java-based program that was produced primarily for the analysis of bibliometric networks. It can create maps of the words in the networks using maps of publications, authors, or journals or frequency of co-existence based on common citation networks. (http://uzgoru.ikc.edu.tr/S/15018/vosviewer).

Selecting databases and journals: In this paper, all publications related to golf tourism published in the WoS database from 1998 to 2020 (March) were analyzed. Due to the relatively low number of studies published in the field of golf tourism, there was no restriction in the selection of journals such as the impact factor of the journal or the field in which it was published.

Data collection and analysis: All searches were made on March 16, 2020, taking into account the daily updates in the WoS database. The following filters are used in the search:

- The studies searched between 1975-2020, the largest range in the database of WoS, were scanned, but the first study published in 1998.

- At the end of the literature study on the subject, the keyword to be searched has been determined as "golf tourism".

Bibliometric analysis can be applied to many types of publications, but its main focus is on articles (Hall, 2011: 16). To achieve more comprehensive results, the search result is not limited to only articles, but all studies have been evaluated.

- The search resulted in 46 studies.

- In the analysis, all the subjects within the scope of golf tourism were gathered under the main title of "golf tourism" and analyzed.

- The studies published between these years were classified as publication type, but each publication was evaluated together.

In this paper, strategic maps and cluster maps were created with SciMAT v1.1.04 program, and network and density maps were created with VOSviewer v1.6.11 program.

\section{Findings}

When the distribution of 46 studies between 1998-2020 (March) is examined, it is seen that most studies were published in 2011-2020 ( $\mathrm{n}=31)$. Studies published after 2011 is $67.4 \%$ of total publications. The number of publications by years is shown in Table 1. The table was created by dividing into two as the time from the year of the first publication to the year when the increase started and the time after the start of the increase. 
Table 1. Distribution of Publications by Years

\begin{tabular}{|c|c|c|}
\hline Years of Publication & Frequency (N) & Percentage (\%) \\
\hline $1998-2010$ & 15 & 32,6 \\
\hline $2011-2020$ & 31 & 67,4 \\
\hline Total & 46 & 100 \\
\hline
\end{tabular}

When the distribution of studies between 1998-2020 (March) is examined by years, it can be seen in Figure 1 that most studies were published in $2015(\mathrm{n}=7)$.

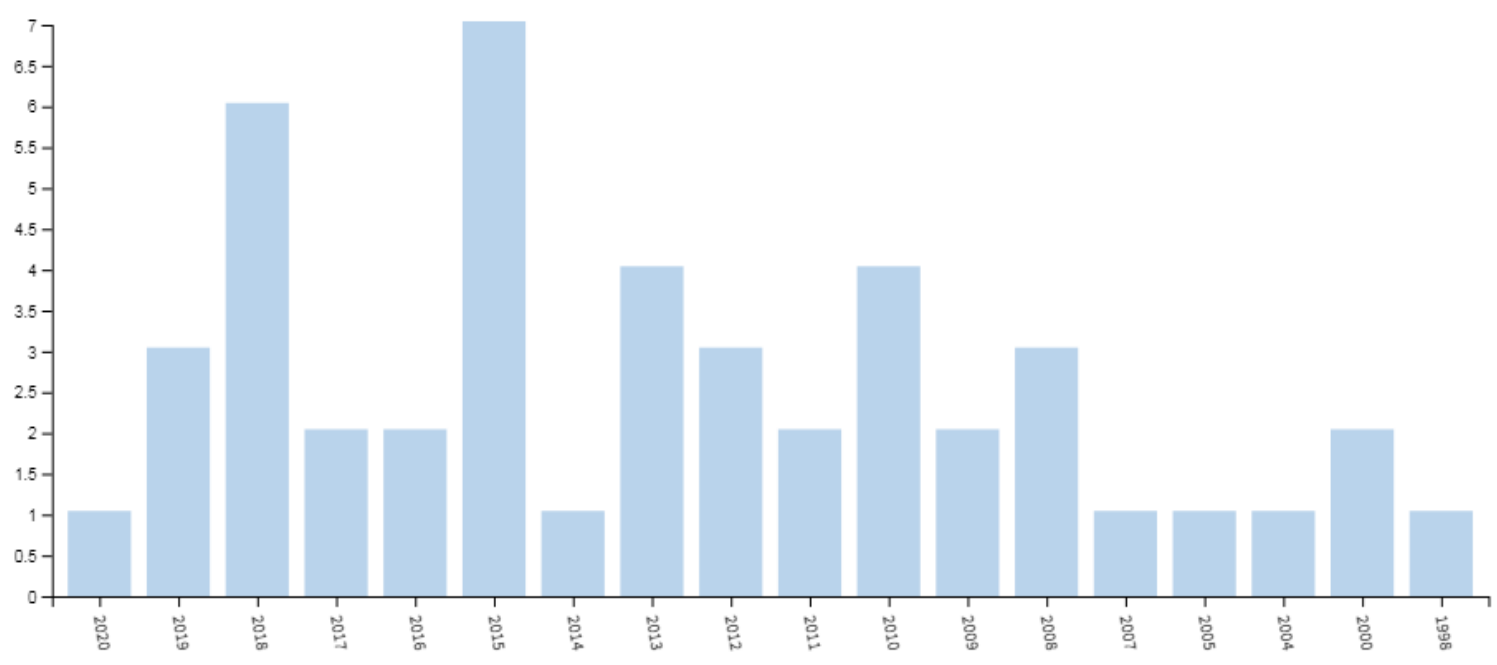

Figure 1. Number of Publications by Year

When the studies published between 1998-2020 (March) were classified according to the types of publications, it was determined that there were 4 different types of publications. Since some studies were evaluated under more than one type, the rates were calculated over 49 publications. The article was determined as the most publication type with a rate of $73.47 \%$ among the publication types. 3 duplicated studies were excluded in subsequent evaluations. All data are shown in Figure 2. 


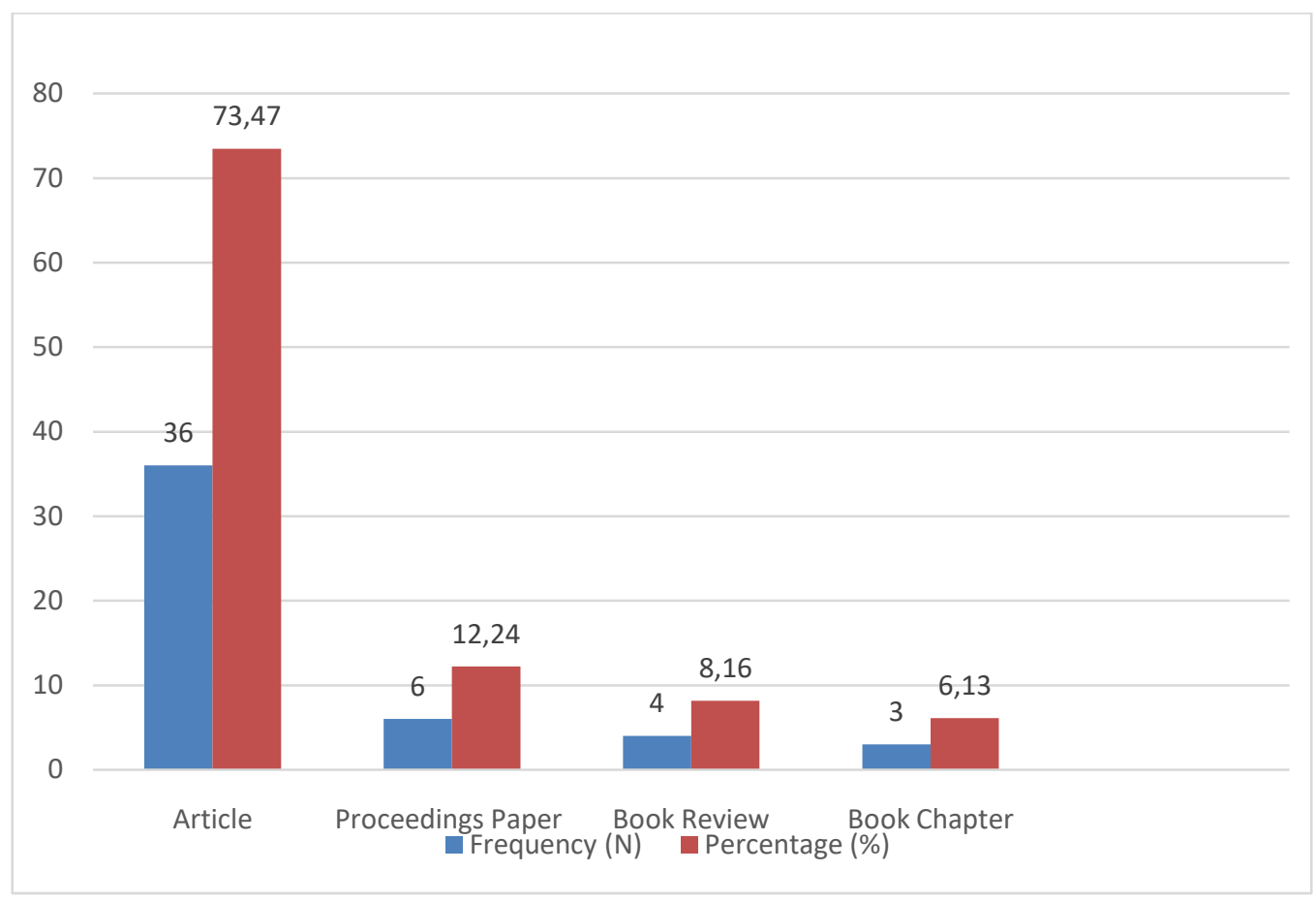

Figure 2. Number of Publication by Types

Studies on golf tourism have been published in 3 different languages in total. $95.66 \%$ of the studies were published in English and the number of Turkish and German publications was only 1 . The distribution of the publications according to the language was given in Figure 3.

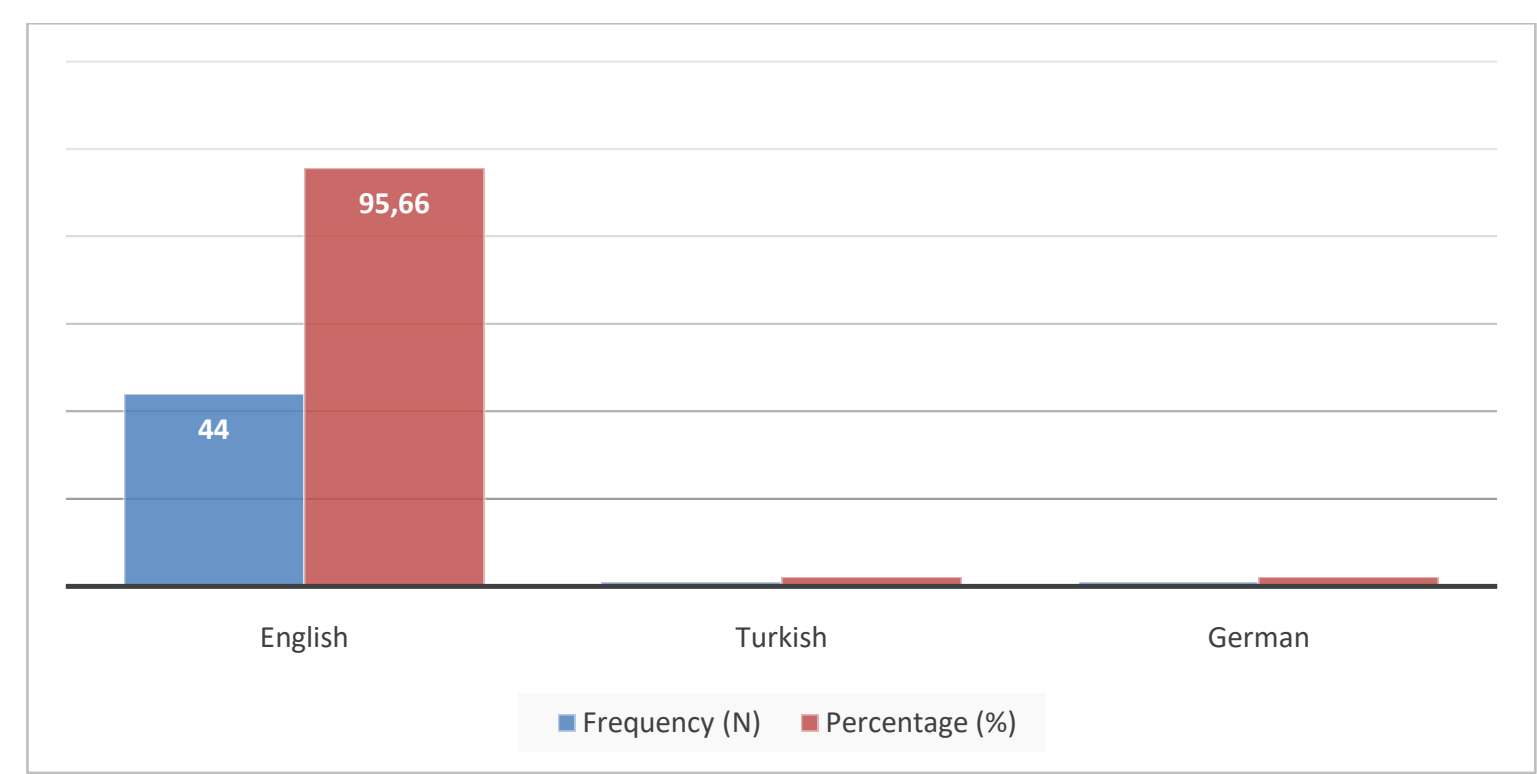

Figure 3. Distribution of Publications by Language

The total number of citations to 46 studies published between 1998-2020 (March) is 400 . 60 of them consist of the citations made by the authors to their works. It was observed that most citations were made in $2019(\mathrm{n}=66)$. Apart from the decrease in 2017 compared to the previous year, the number of citations received increased every year. While the average 
number of citations per study is 8.7 in 46 publications, the average number of citations per year is 19.05. In Figure 4, the number of citations by year is given in detail.

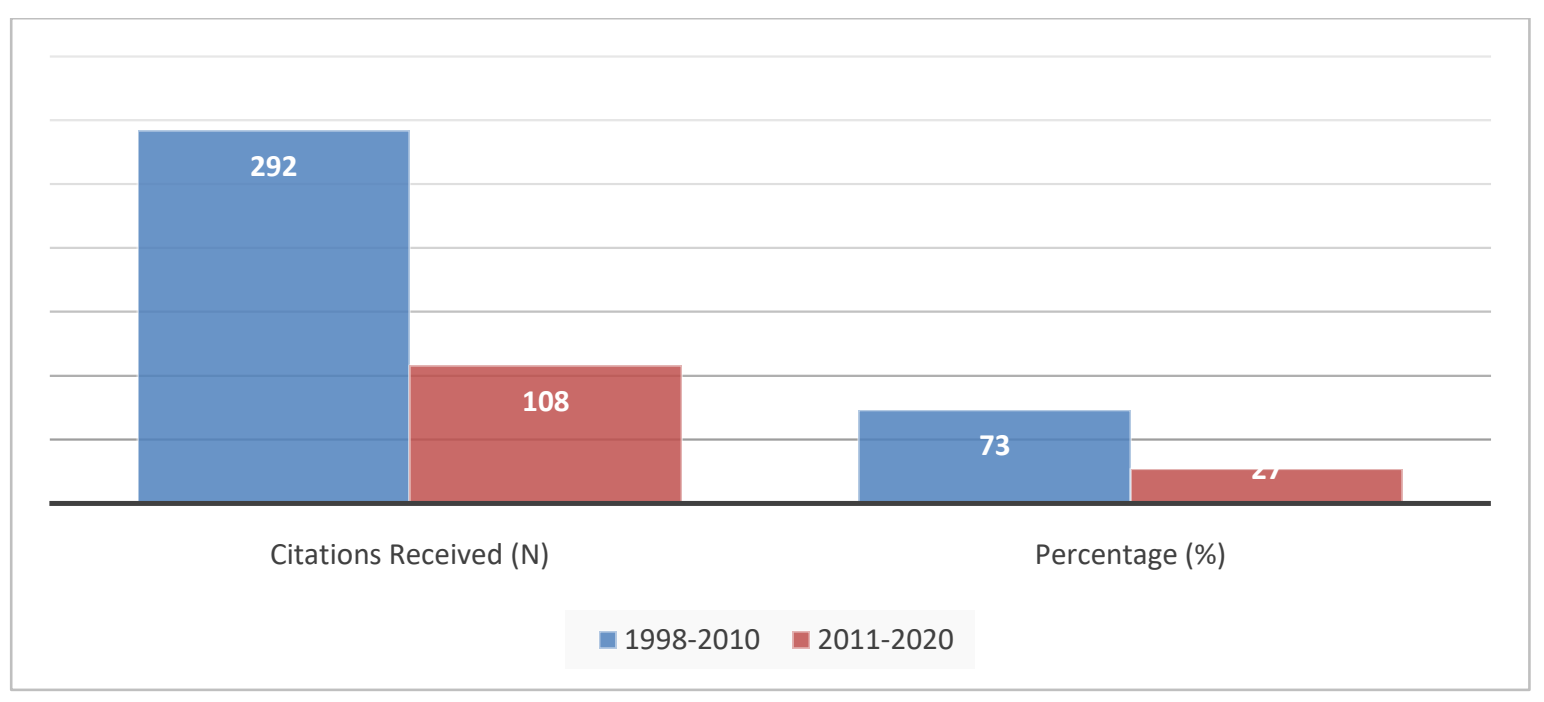

Figure 4. Number of Citations by Year

When the number of publications is analyzed by countries, the highest number of publications came out of England $(n=8)$. Spain and the USA $(n=7)$ were the second most broadcast countries. In Figure 5, the distribution of publications by countries is given.

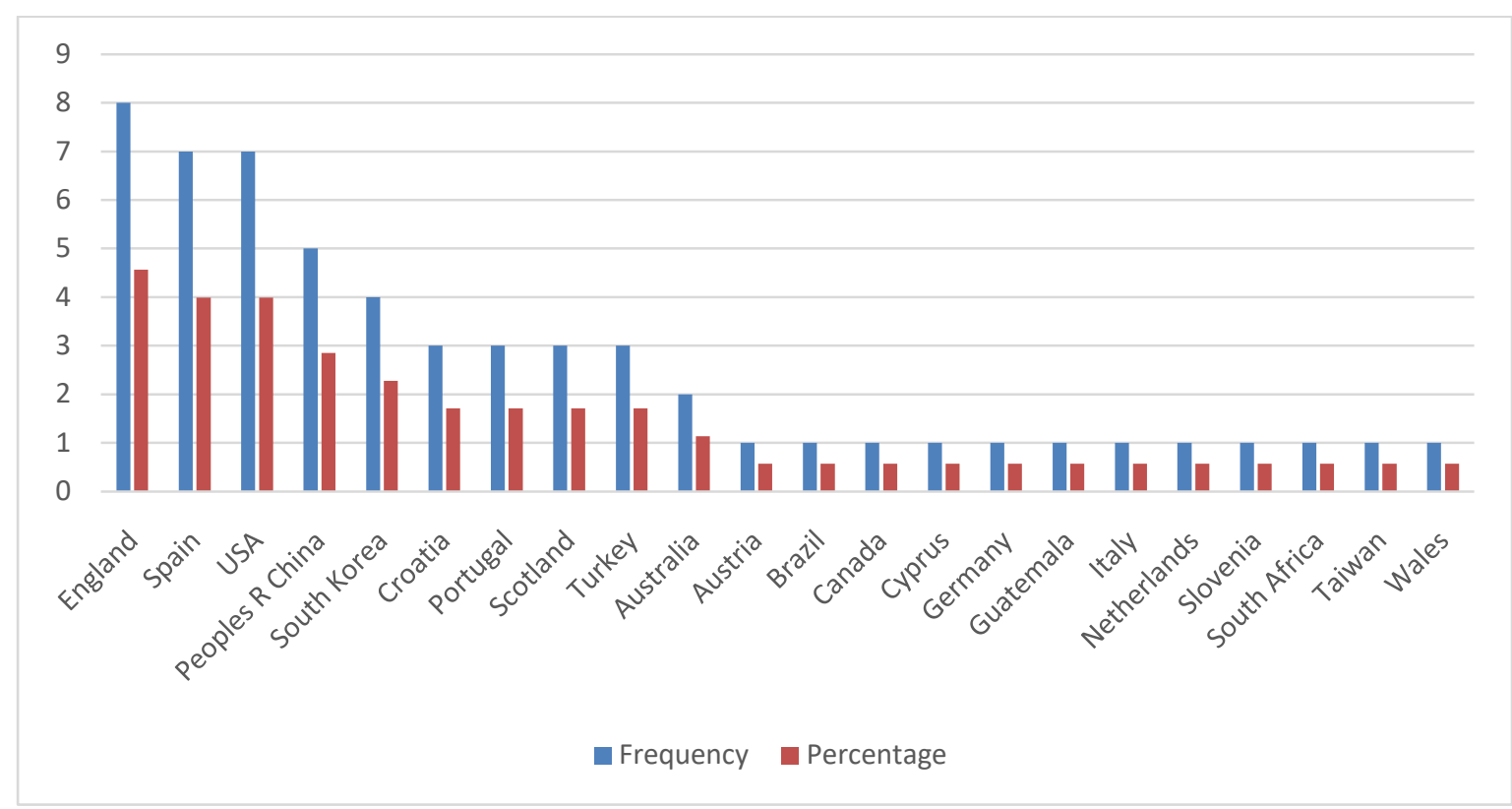

Figure 5. Number of Publications by Countries

Barros et al. (2010)'s paper "The length of stay of golf tourism: a survival analysis" is the most cited work in the field with 84 citations. It can be said that this paper is the most important source that sheds light on other studies on golf tourism. This paper is followed by Markwick (2000) with 78 citations and Tassiopoulos and Haydam (2008) with 41 citations. The most cited authors are shown in Table 2. 
Table 2. Most Cited Authors

\begin{tabular}{|c|c|c|c|c|}
\hline Publication Name & Author(s) & Source & Year & $\begin{array}{c}\text { Number of } \\
\text { Citation }\end{array}$ \\
\hline $\begin{array}{c}\text { The length of stay of golf tourism: a } \\
\text { survival analysis }\end{array}$ & $\begin{array}{l}\text { Barros, Carlos Pestana; Butler, } \\
\text { Richard; Correia, Antonia }\end{array}$ & $\begin{array}{c}\text { Tourism } \\
\text { Management }\end{array}$ & 2010 & 84 \\
\hline $\begin{array}{l}\text { Golf tourism development, stakeholders, } \\
\text { differing discourses and alternative } \\
\text { agendas: the case of Malta }\end{array}$ & Markwick, MC & $\begin{array}{c}\text { Tourism } \\
\text { Management }\end{array}$ & 2000 & 78 \\
\hline $\begin{array}{l}\text { Golf tourists in South Africa: a demand- } \\
\text { side study of a niche market in sports } \\
\text { tourism }\end{array}$ & $\begin{array}{c}\text { Tassiopoulos, Dimitri; Haydam, } \\
\text { Norbert }\end{array}$ & $\begin{array}{c}\text { Tourism } \\
\text { Management }\end{array}$ & 2008 & 41 \\
\hline $\begin{array}{c}\text { Motivation-based Typology: an Empirical } \\
\text { Study of Golf Tourists }\end{array}$ & Kim, Jae Hak; Ritchie, Brent W. & $\begin{array}{c}\text { Journal of } \\
\text { Hospitality \& } \\
\text { Tourism Research }\end{array}$ & 2012 & 33 \\
\hline $\begin{array}{l}\text { Positioning analysis of overseas golf tour } \\
\text { destinations by Korean golf tourists }\end{array}$ & Kim, SS; Chun, H; Petrick, JF & $\begin{array}{c}\text { Tourism } \\
\text { Management }\end{array}$ & 2005 & 28 \\
\hline $\begin{array}{c}\text { Segmenting Overseas Golf Tourists by the } \\
\text { Concept of Specialization }\end{array}$ & $\begin{array}{l}\text { Kim, Samuel Seongseop; Kim, Jae } \\
\text { Hak; Ritchie, Brent W. }\end{array}$ & $\begin{array}{l}\text { Journal of Travel \& } \\
\text { Tourism Marketing }\end{array}$ & 2008 & 24 \\
\hline $\begin{array}{c}\text { A cross national study of golf tourists' } \\
\text { satisfaction }\end{array}$ & $\begin{array}{l}\text { Moital, Miguel; Dias, Nuno Ricardo; } \\
\text { Machado, Danielle F. C. }\end{array}$ & $\begin{array}{c}\text { Journal of } \\
\text { Destination } \\
\text { Marketing \& } \\
\text { Management }\end{array}$ & 2013 & 15 \\
\hline $\begin{array}{l}\text { Applying Systems Thinking to Sustainable } \\
\text { Golf Tourism }\end{array}$ & Woodside, Arch G. & $\begin{array}{c}\text { Journal of Travel } \\
\text { Research }\end{array}$ & 2009 & 11 \\
\hline $\begin{array}{l}\text { The mediating effect of place attachment } \\
\text { on the relationship between golf tourism } \\
\text { destination image and revisit intention }\end{array}$ & $\begin{array}{c}\text { Song, Hui-Min; Kim, Kyung-Sik; } \\
\text { Yim, Brian H. }\end{array}$ & $\begin{array}{c}\text { Asia Pacific Journal } \\
\text { of Tourism } \\
\text { Research }\end{array}$ & 2017 & 10 \\
\hline $\begin{array}{l}\text { Are eco labels profitably employed in } \\
\text { sustainable tourism? A case study on } \\
\text { Audubon Certified Golf Resorts }\end{array}$ & $\begin{array}{l}\text { Minoli, Dino M.; Goode, Mark M. } \\
\text { H.; Smith, Mark T. }\end{array}$ & $\begin{array}{c}\text { Tourism } \\
\text { Management } \\
\text { Perspectives }\end{array}$ & 2015 & 10 \\
\hline $\begin{array}{c}\text { The rejuvenation of tourism in Barbados } \\
\text { 1993-2003 - Reflections oil the Butler } \\
\text { model }\end{array}$ & Potter, RB; Phillips, J & Geography & 2004 & 9 \\
\hline $\begin{array}{l}\text { Tourism, globalisation and critical security } \\
\text { in Myanmar and Thailand }\end{array}$ & Parnwell, MJG & $\begin{array}{l}\text { Singapore Journal } \\
\text { of Tropical } \\
\text { Geography }\end{array}$ & 1998 & 8 \\
\hline $\begin{array}{l}\text { Evaluation of ecotourism sites: a GIS- } \\
\text { based multi-criteria decision analysis }\end{array}$ & $\begin{array}{l}\text { Cetinkaya, Cihan; Kabak, Mehmet; } \\
\text { Erbas, Mehmet; Ozceylan, Eren }\end{array}$ & Kybernetes & 2018 & 7 \\
\hline $\begin{array}{l}\text { From the new environmental paradigm to } \\
\text { the brief ecological paradigm: a revised } \\
\text { scale in golf tourism }\end{array}$ & $\begin{array}{l}\text { Miguel Lopez-Bonilla, Luis; Manuel } \\
\text { Lopez-Bonilla, Jesus }\end{array}$ & $\begin{array}{c}\text { Anatolia- } \\
\text { International } \\
\text { Journal of Tourism } \\
\text { and Hospitality } \\
\text { Research }\end{array}$ & 2016 & 7 \\
\hline Identification of Segments for Overseas & Ramirez-Hurtado, Jose M.; Berbel- & Journal of & 2015 & 5 \\
\hline
\end{tabular}




\begin{tabular}{|c|c|c|c|c|}
\hline $\begin{array}{l}\text { Tourists Playing Golf in Spain: A Latent } \\
\text { Class Approach }\end{array}$ & Pineda, Juan M. & $\begin{array}{c}\text { Hospitality } \\
\text { Marketing \& } \\
\text { Management }\end{array}$ & & \\
\hline $\begin{array}{c}\text { Integrating cumulative impacts into } \\
\text { strategic environmental decision-making: } \\
\text { Tourism development in Belek, Turkey }\end{array}$ & Unalan, Dilek & Land Use Policy & 2013 & 5 \\
\hline $\begin{array}{l}\text { Treatment of travel expenses by golf } \\
\text { course patrons: Sunk or bundled costs and } \\
\text { the first and third laws of demand }\end{array}$ & $\begin{array}{l}\text { Brown, Matthew T.; Rascher, Daniel } \\
\text { A.; McEvoy, Chad D.; Nagel, Mark } \\
\text { S. }\end{array}$ & $\begin{array}{c}\text { International } \\
\text { Journal of Sport } \\
\text { Finance }\end{array}$ & 2007 & 5 \\
\hline $\begin{array}{c}\text { Analysis of the efficiency of golf tourism } \\
\text { via the Internet. Application to the } \\
\text { Mediterranean countries }\end{array}$ & $\begin{array}{l}\text { Pastor Ciurana, Jesus T.; Del Campo } \\
\text { Gomis, Francisco J.; Vidal Gimenez, } \\
\text { Fernando; Pastor Campos, Diego; } \\
\text { Agullo Torres, Asuncion }\end{array}$ & $\begin{array}{l}\text { Current Issues in } \\
\text { Tourism }\end{array}$ & 2015 & 4 \\
\hline Golf Tourism: The Case of Cyprus & $\begin{array}{c}\text { Boukas, Nikolaos; Boustras, George; } \\
\text { Sinka, Alexandros }\end{array}$ & $\begin{array}{c}\text { Controversies in } \\
\text { Tourism }\end{array}$ & 2012 & 3 \\
\hline $\begin{array}{c}\text { Golf Tourism, its institutional setting, and } \\
\text { environmental management: a longitudinal } \\
\text { analysis }\end{array}$ & $\begin{array}{c}\text { Vargas-Sanchez, Alfonso; Riquel- } \\
\text { Ligero, Francisco }\end{array}$ & $\begin{array}{l}\text { European Journal } \\
\text { of Tourism } \\
\text { Research }\end{array}$ & 2015 & 2 \\
\hline $\begin{array}{l}\text { Golf tourism and the trip decision-making } \\
\text { process: the influence of lifestage, } \\
\text { negotiation and compromise, and the } \\
\text { existence of tiered decision-making units }\end{array}$ & Humphreys, Claire J.; Weed, Mike & Leisure Studies & 2014 & 2 \\
\hline $\begin{array}{l}\text { Environmental considerations for } \\
\text { feasibility of new golf course development } \\
\text { in Alicante province (Spain) }\end{array}$ & $\begin{array}{l}\text { Del Campo Gomis, Francisco J.; } \\
\text { Lopez Lluch, David B.; Sales } \\
\text { Civera, Jose M.; Agullo Torres, } \\
\text { Asuncion M.; Lagos Milla, Jesus }\end{array}$ & $\begin{array}{l}\text { Journal of Food } \\
\text { Agriculture \& } \\
\text { Environment }\end{array}$ & 2010 & 2 \\
\hline $\begin{array}{c}\text { Contributions of tourism to destination } \\
\text { sustainability: golf tourism in St Andrews, } \\
\text { Scotland }\end{array}$ & Butler, Richard William & Tourism Review & 2019 & 1 \\
\hline $\begin{array}{l}\text { The Environmental Attitudes and } \\
\text { Behaviours of European Golf Tourists }\end{array}$ & $\begin{array}{c}\text { Manuel Lopez-Bonilla, Jesus; del } \\
\text { Carmen Reyes-Rodriguez, Maria; } \\
\text { Miguel Lopez-Bonilla, Luis }\end{array}$ & Sustainability & 2018 & 1 \\
\hline $\begin{array}{c}\text { Korean Golf Tourism in China: Place, } \\
\text { Perception and Narratives }\end{array}$ & $\begin{array}{l}\text { Park, Jinah; Morrison, Alastair M.; } \\
\text { Wu, Bihu; Kong, Yeung }\end{array}$ & Sustainability & 2018 & 1 \\
\hline $\begin{array}{l}\text { Climate variability and water use on golf } \\
\text { courses: optimization opportunities for a } \\
\text { warmer future }\end{array}$ & $\begin{array}{l}\text { Scott, Daniel; Rutty, Michelle; } \\
\text { Peister, Carly }\end{array}$ & $\begin{array}{c}\text { Journal of } \\
\text { Sustainable } \\
\text { Tourism }\end{array}$ & 2018 & 1 \\
\hline $\begin{array}{l}\text { Antecedents and moderators of golf } \\
\text { tourists' behavioral intentions An } \\
\text { empirical study in a Mediterranean } \\
\text { destination }\end{array}$ & Mason, Michela C.; Moretti, Andrea & $\begin{array}{c}\text { Euromed Journal of } \\
\text { Business }\end{array}$ & 2015 & 1 \\
\hline $\begin{array}{l}\text { Macroeconomic Legitimacy of Investment } \\
\text { in the Development of Golf Tourism in } \\
\text { Istria }\end{array}$ & $\begin{array}{c}\text { Jugovic, Alen; Grzinic, Jasmina; } \\
\text { Loncar, Slavko }\end{array}$ & $\begin{array}{l}\text { Economic } \\
\text { Research- } \\
\text { Ekonomska } \\
\text { Istrazivanja }\end{array}$ & 2009 & 1 \\
\hline
\end{tabular}




\begin{tabular}{|c|c|c|c|}
\hline $\begin{array}{c}\text { The impact of golf course management on } \\
\text { concentrations of nutrients in the soil } \\
\text { solution }\end{array}$ & $\begin{array}{c}\text { Fodgornik, Maja; Pastor, Marc; } \\
\text { Environmental } \\
\text { Bulletin }\end{array}$ & 2008 & 1 \\
\hline
\end{tabular}

VOSviewer software was used in this study to get an overall view of the results. This program provides a graphical analysis of bibliographic material. In Figure 6, there is a citation map according to the authors. The size of the nodes on the map grows in proportion to the number of citations. Barros et al. (2010) 84 and Markwick (2000) are considered as the largest nodes because they are the most cited studies with 78 citations.

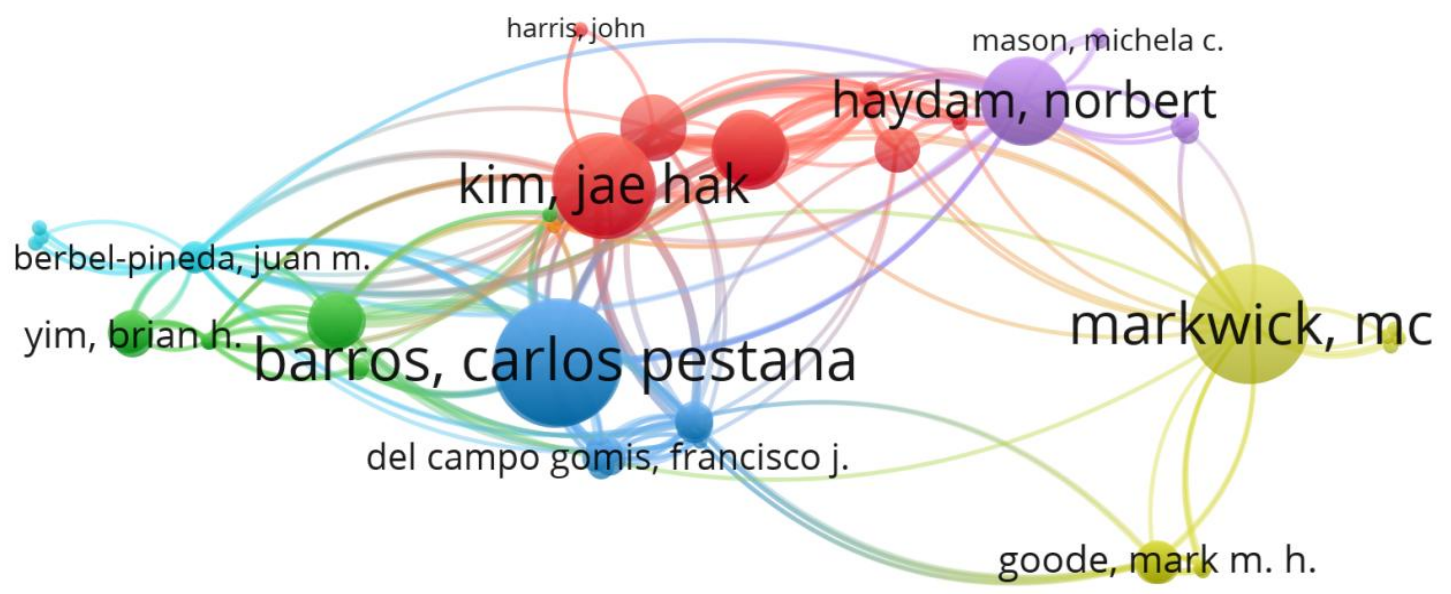

VOSviewer

Figure 6. Author Citation Network

According to the authors, the density map of the citations is shown in Figure 7 . In this figure, Barros et al. (2010) and Markwick (2000) appear to be more cited and centralized than other authors. 


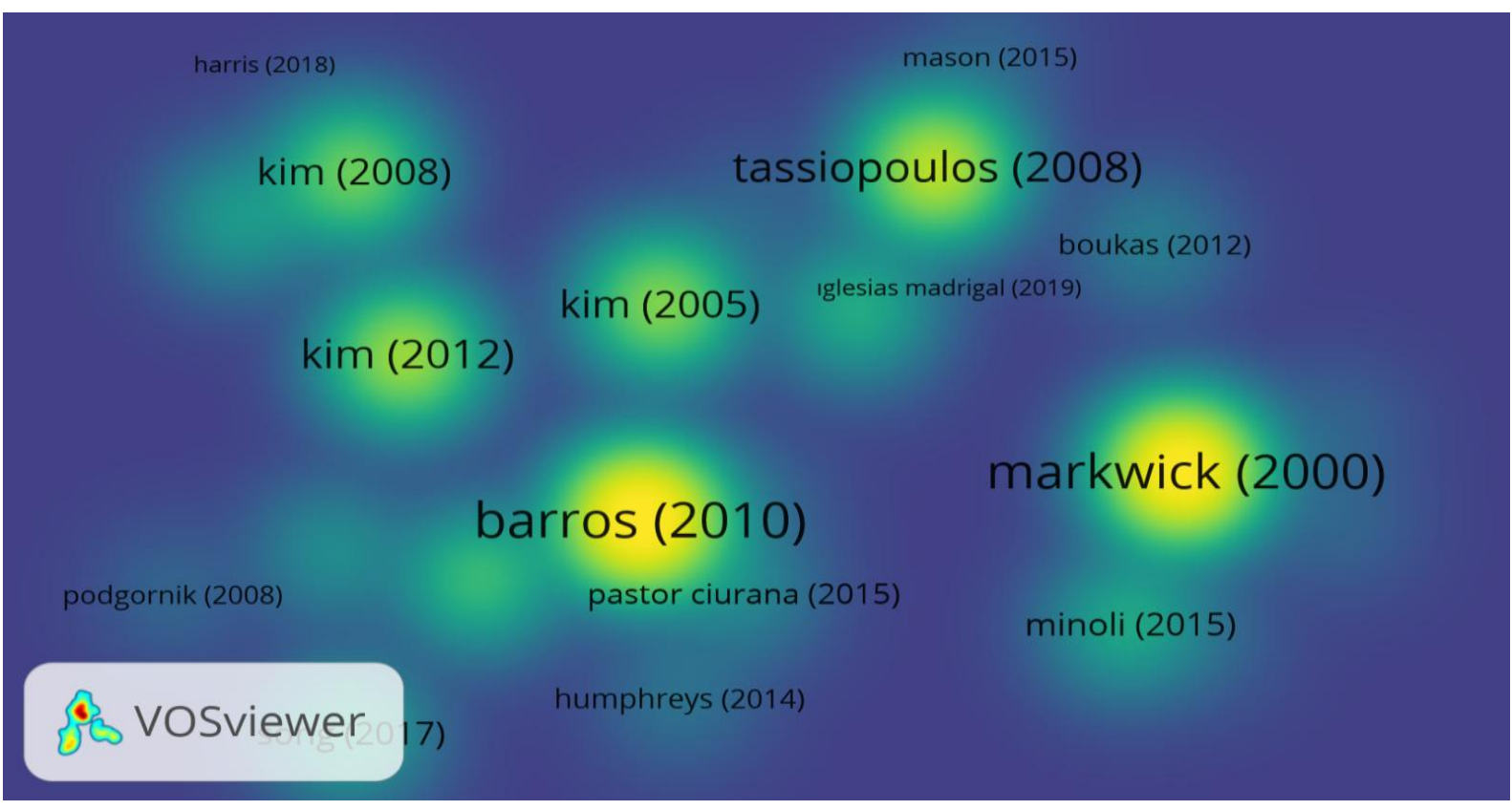

Figure 7. Density Map of Citations

The journal citation network aims to identify the most cited journals and leading journals in golf tourism among the studies on golf tourism. As a result of the analysis, the network is divided into 7 clusters and the total strength between the clusters is 38 . The network consists of 18 nodes and 28 links. When Figure 8 is examined, the most-cited journal is the "Tourism Management" with 6 citations.

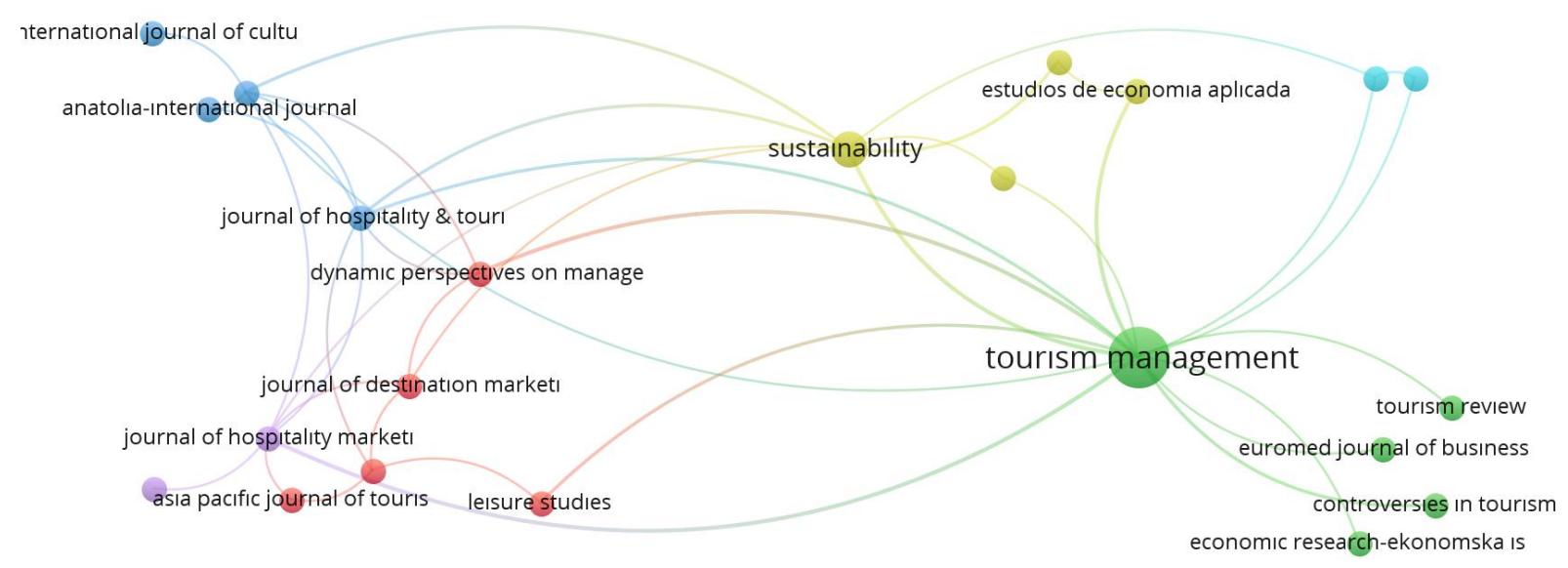

Figure 8. Journal Citation Network

To determine the studies in different countries, a country collaborations network has been made. Country names are sized according to their centrality and are shown in Figure 9. 


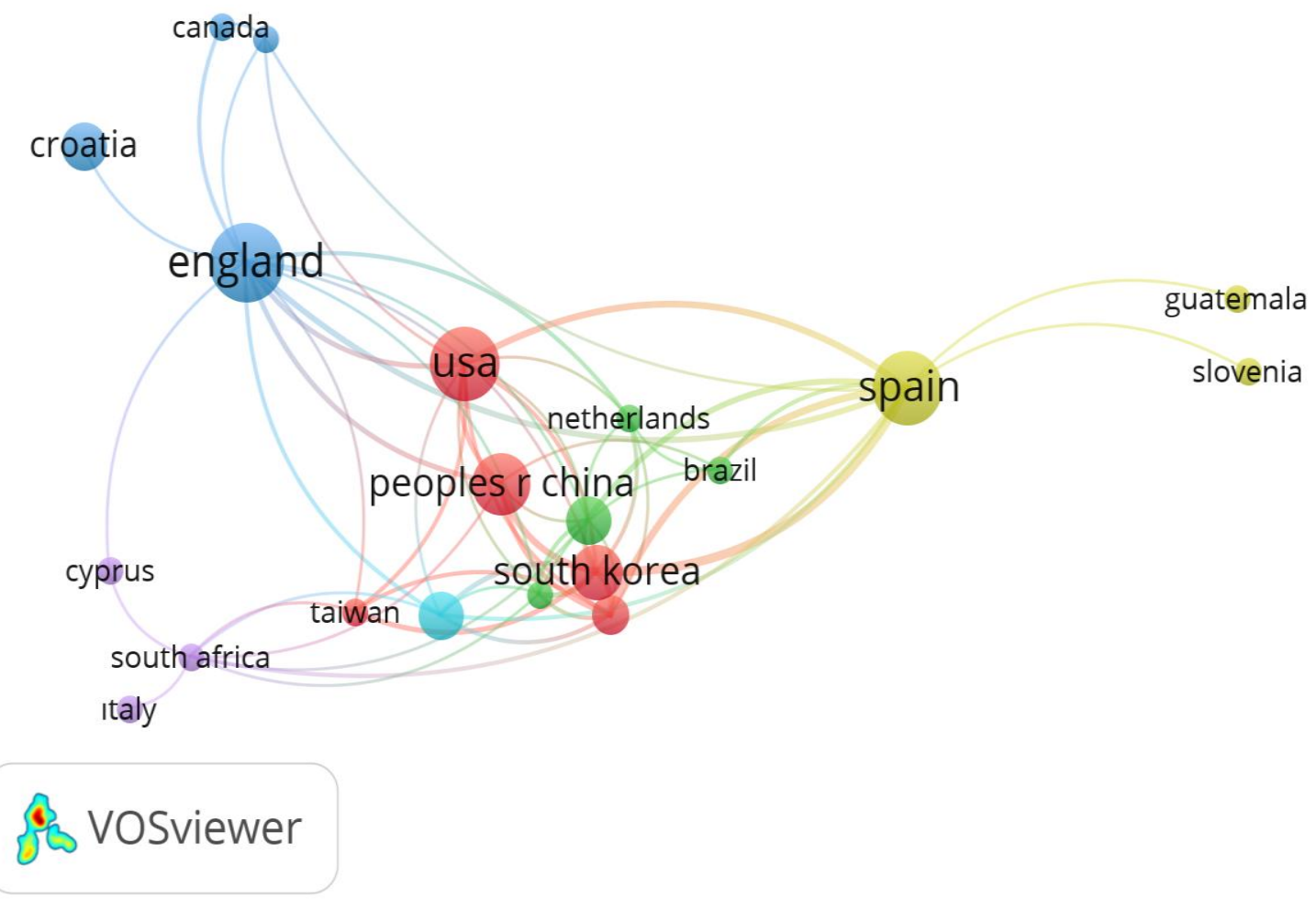

Figure 9. Country Collaborations

When analyzing country collaborations, countries were taken into consideration once in the studies involving more than one author from the same country. In the network, each node indicates a country, and each link indicates the relations between countries. The connections between nodes become thicker as the number of connections increases. As a result of the analysis, a network of 15 nodes and 58 connections was obtained. The network is divided into 5 clusters and its density is 0.09 . When analyzed on the map, Spain, South Korea, and the England stand out as the most publishing countries on the subject. It has been found that Spain is in cooperation with 17 countries, South Korea with 15 countries and England with 13 countries. From this point of view, it can be said that Spain plays a key role in providing scientific relations between countries and acts as a bridge. When the cooperation and total connection powers of the countries are analyzed, it is determined that Spain's connection power is 11 , South Korea is 10, and England is 13. 
canada

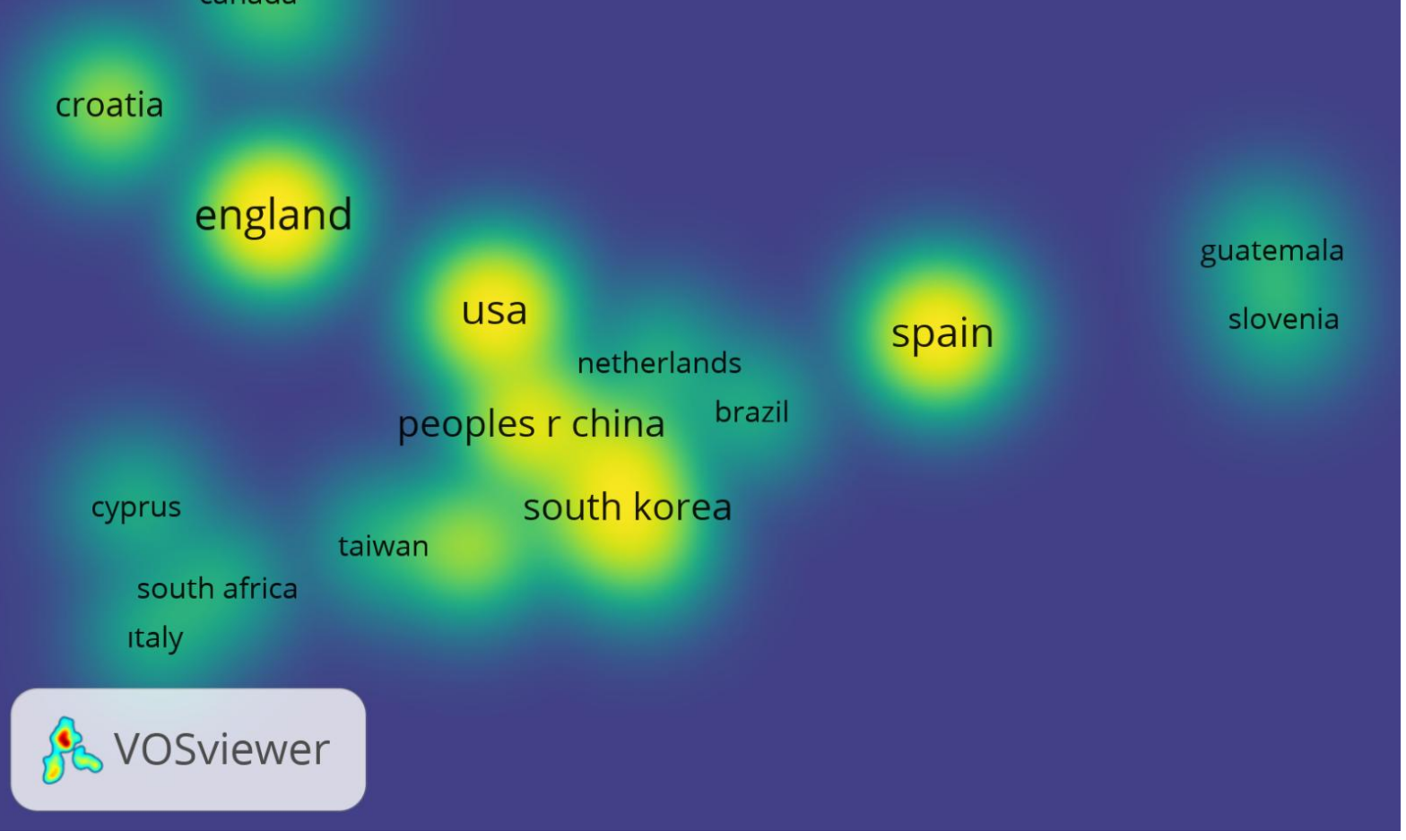

Figure 10. The Density of Country Collaborations

When the density map in Figure 10 is examined, it is seen that Spain is in a position that feeds the center and other countries. The density of the color of Spain, South Korea, and England on the density map shows that these countries are more than their other publications about golf tourism.

When the clusters formed according to citation sources are examined, it is seen that the subject of golf tourism has strong ties with the subjects of "behavior", "destination", "marketing", "tourism", and "sustainability". Besides, it is seen that marketing and destination themes and tourism and sustainability themes form strong links among themselves. The cluster map regarding golf tourism is presented in Figure 11. 


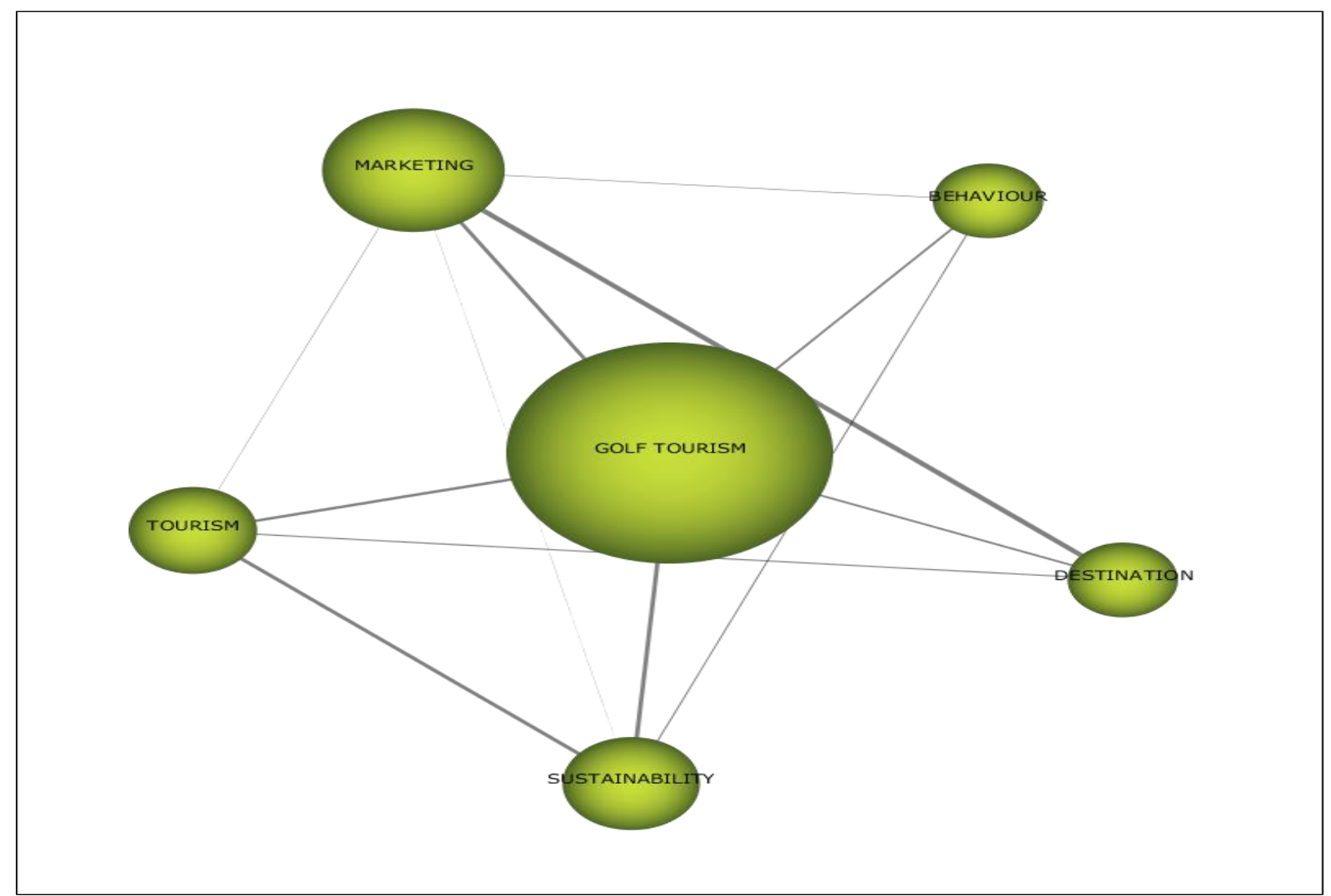

Figure 11. Cluster Analysis

When the centrality and density map of publications related to golf tourism are examined; "intention" as the engine theme in the upper right, "motivation" as the basic theme in the lower right and the theme of "management" in the topics open to working in the lower left. The centrality and density map of publications are presented in Figure 12. 


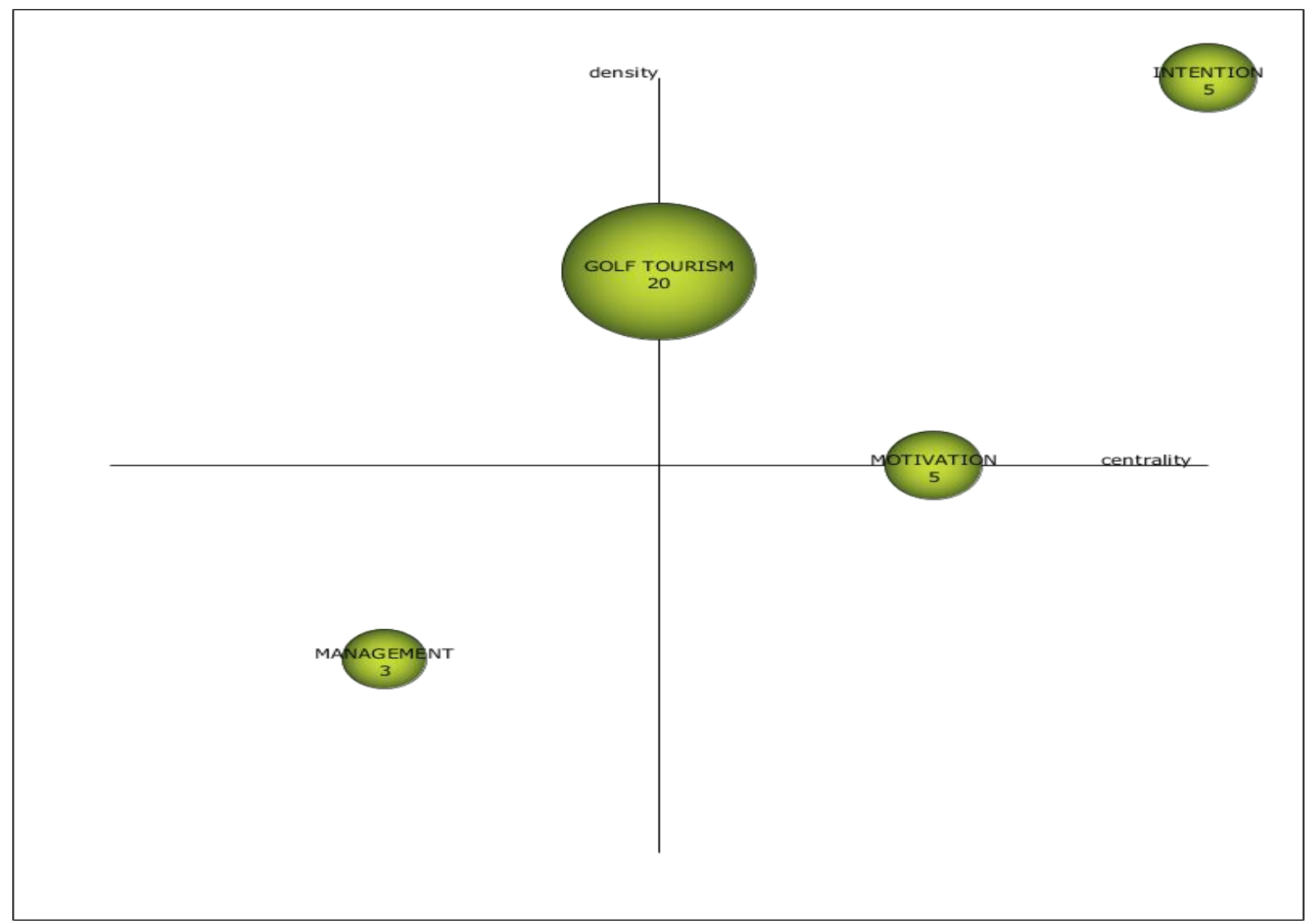

Figure 12. Map of Centrality and Density

The degree of strength of the relationship of the theme with other themes or thematic fields is shown on the strategic map. In this map, there is "centrality" on the horizontal axis and "density" on the vertical axis. As the degree of centrality increases, the relationship of the related theme with other themes increases, and as the degree of centrality decreases, the relationship force decreases. Density refers to the frequency of broadcasting, and the frequency of broadcasting increases as you go to the right on the map and decreases as you go to the left (Yıldiz \& Aykanat, 2015).

In the upper-right part of the map, there are main themes with the highest density and centrality. In the lower right part of the map, there are basic themes with high centrality but less density than the main themes. Themes in the upper left part of the map are powerful but isolated themes. Rising or disappearing themes are themes located in the lower-left part of the map (Cobo et al., 2012: 1609-1630).

When the centrality and density of the publications on golf tourism are examined; the centrality of the golf tourism theme was 49.62 and the density was 0.75 . The density of the "Intention" theme is 88.31 , and its centrality value is 55.01 . In Table 3, the centrality and density values and weights of the items in the strategic map are given. 
Table 3. Centrality and Density Values

\begin{tabular}{|c|c|c|c|c|}
\hline Cluster & Centrality & Centrality Weight & Density & Density Weight \\
\hline Golf Tourism & 49.62 & 0.5 & 35.45 & 0.75 \\
\hline Intention & 55.01 & 1 & 88.31 & 1 \\
\hline Management & 21.46 & 0.25 & 7.94 & 0.25 \\
\hline Motivation & 51.34 & 0.75 & 18.55 & 0.5 \\
\hline
\end{tabular}

When Figure 13 is examined; the "intention" theme can be expressed as the main theme as it is located in the upper right part of the map and as a subject that is open to research because the management issue is in the lower-left part. Since the "motivation" theme is at the bottom right and is within the scope of the basic theme, and it can be expressed as the most studied subject in golf tourism.

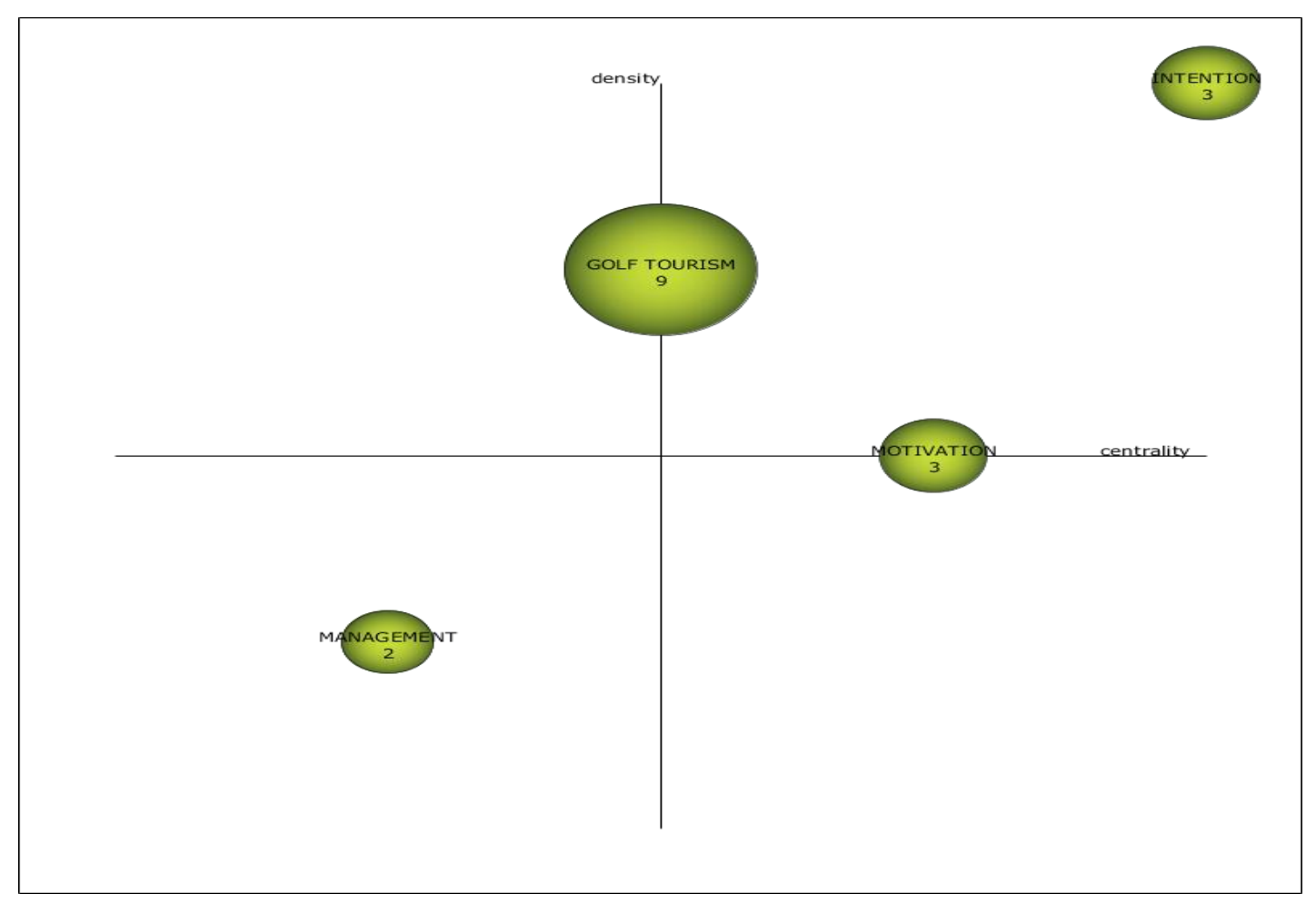

Figure 13. Strategic Map (h-index)

\section{Conclusion and Suggestions}

With the evaluation of golf tourism studies, we aimed to reveal the changes and trends in this field in the last 22 years. So, in the "golf tourism" topic in the WoS database, the reviewing was carried out between 1998-2020, and the data of the published studies on the subject were obtained. The bibliometric scientific mapping method was used to perform the analysis utilizing the SciMAT and VOSviewer software platforms. 
Since some studies were evaluated under more than one type of publication, all publications consisted of 36 articles, 6 proceedings paper, 4 book reviews, and 3 book chapters $(\mathrm{n}=49)$. When 46 studies between 1998-2020 (March) on golf tourism were examined, it was found that $67.4 \%(\mathrm{n}=31)$ of the publications were published after 2011 . Most published studies in this field in 2015. Most of the publications $(n=44)$ were published in English and there is only 1 Turkish and 1 German publication. As in all other fields, it is an expected conclusion that English is the preferred language in golf tourism.

The total number of citations for golf tourism is 400 and 60 of them are citations made by the authors for their work. It is not surprising that the self-citation rate of the authors is low due to the low number of studies on this subject. The fact that the highest reference to 46 studies was made in 2019 with 66 is thought to be related to the increasing popularity of the subject of golf tourism.

In the list of countries that publish the most on golf tourism, England has the highest number of publications with 8 , Spain 7 , USA 7 and China 5. The number of publications from Turkey is only 3 . Therefore, researchers from some countries can contribute to the literature by making more publications on golf tourism from different perspectives.

The most cited $(\mathrm{n}=84)$ study is Barros et al. (2010) "The length of stay of golf tourism: a survival analysis" study. Markwick's (2000) study of "Golf tourism development, stakeholders, differing discourses and alternative agendas: the case of Malta" is the second most cited $(n=78)$ study. Moreover, the most cited journal is "Tourism Management". The journal of Tourism Management, which is one of the most prestigious journals in its field, stands out as a valuable journal for researchers in terms of both publishing and using it as a resource. Bournemouth University has more academic publications between all universities (n = 3). Also, Adana Alparslan Türkeş Science and Technology University $(n=1)$, Gazi University $(\mathrm{n}=1)$ and Bogazici University $(\mathrm{n}=1)$ has contributed to the area by the publication.

"Tourism", "sustainability", "marketing", "behavior", and "destination" are the prominent themes in publications related to golf tourism. The theme with the highest centrality and density value is the "intention" and the "management" theme is a rising theme. This result is an indication that there is still a deficiency in the literature regarding the researches related to the administrative dimension of golf tourism. When the subject clusters formed according to the citation sources are examined, it is seen that the subject of golf tourism has strong ties with the subjects of "behavior", "destination", "marketing", "tourism" and "sustainability". It is expected to have strong ties with the above-mentioned subjects in terms of golf tourism. 
Future golf tourism studies may focus increasingly on intention and management issues. However, because of the relatively small number of studies on golf tourism in general, all kinds of studies should be considered as contributing to the literature in the field.

\section{Limitations of the Study}

As with any scientific study, this study has its limitations. It can be suggested that future studies will be carried out with a larger database. Future studies can use other databases besides WoS and also consider doctoral dissertations. Researchers, who will research tourism, sports tourism, and golf tourism, may be suggested to evaluate the subject in terms of management. Additionally, different bibliometric analyses can be applied to better understand the evolution of golf tourism, including co-citation, co-authoring, co-word analysis, and author keyword set analysis. 


\section{REFERENCES}

Barrios, M., Borrego, A., Vilaginés, A., Ollé, C., \& Somoza, M. (2008). A Bibliometric Study of Psychological Research on Tourism. Scientometrics, 77(3), 453-467.

Barros, C. P., Butler, R., \& Correia, A. (2010). The Length of Stay of Golf Tourism: A Survival Analysis. Tourism Management, 31(1), 13-21.

Broadus, R. (1987). Toward a Definition of "Bibliometrics". Scientometrics, 12(5-6), 373-379.

Boyack, K. W., Klavans, R., \& Börner, K. (2005). Mapping the Backbone of Science. Scientometrics, 64(3), 351-374.

Bozok, D., Kılıç, S. N., \& Özdemir, S. S. (2017). Turizm Literatüründe Kırsal Turizmin Bibliyometrik Analizi. Journal of Human Sciences, 14(1), 187-202.

Boukas, N., Boustras, G., \& Sinka, A. (2012). 10 Golf Tourism: The Case of Cyprus. Controversies in Tourism, 144.

Cancino, C., Merigó, J. M., Coronado, F., Dessouky, Y., \& Dessouky, M. (2017). Forty Years of Computers \& Industrial Engineering: A Bibliometric Analysis. Computers \& Industrial Engineering, 113, 614-629.

Cobo, M. J., López-Herrera, A. G., Herrera-Viedma, E., \& Herrera, F. (2011). Science Mapping Software Tools: Review, Analysis, and Cooperative Study Among Tools. Journal of the American Society for Information Science and Technology, 62(7), 1382-1402.

Cobo, M. J., López-Herrera, A. G., Herrera-Viedma, E., \& Herrera, F. (2012). SciMAT: A New Science Mapping Analysis Software Tool. Journal of the American Society for Information Science and Technology, 63(8), 1609-1630.

Çetinkaya, G., \& Dedemen, O. (2013). Golf Turizmine Yönelik Yerel Halkın Algılarının Belirlenmesi: Antalya/Belek Örneği. Turar Turizm ve Araştırma Dergisi, 2(1), 24-45.

Garrigos-Simon, F. J., Narangajavana-Kaosiri, Y., \& Lengua-Lengua, I. (2018). Tourism and Sustainability: A Bibliometric and Visualization Analysis. Sustainability, 10(6), 1976.

Güzeller, C. O., \& Çeliker, N. (2018). Bibliometric Analysis of Tourism Research for the Period 2007-2016. Advances in Hospitality and Tourism Research (AHTR), 6(1), 1-22.

Hall, C. M. (2011). Publish and perish? Bibliometric Analysis, Journal Ranking and The Assessment of Research Quality in Tourism. Tourism Management, 32(1), 16-27.

Han, H., Yoon, H., \& Woods, D. P. (2016). Role of environmental consciousness in golfers' decision formation in the traditional and screen-golf industries. Journal of Quality Assurance in Hospitality \& Tourism, 17(3), 290-310.

Hudson, S. (2003). Sport and adventure Tourism. New York The Haworth Hospitality Press.

Hudson, S. (2010). Golf Tourism. Woodeaton, Oxford: Goodfellow Publishers Limited.

http://uzgoru.ikc.edu.tr/S/15018/vosviewer (Erişim Tarihi: 20.03.2020).

Hutchinson, J., Lai, F., \& Wang, Y. (2009). Understanding the relationships of quality, value, equity, satisfaction, and behavioral intentions among golf travelers. Tourism Management, 30(2), 298-308.

Jiménez-Caballero, J. L., \& Polo Molina, S. (2017). A Bibliometric Analysis of the Presence of Finances in High-Impact Tourism Journals. Current Issues in Tourism, 20(3), 225-232.

Jiménez-García, M., Ruiz-Chico, J., Peña-Sánchez, A. R., \& López-Sánchez, J. A. (2020). A bibliometric analysis of sports tourism and sustainability (2002-2019). Sustainability, 12(7), 2840.

Koseoglu, M. A., Rahimi, R., Okumus, F., \& Liu, J. (2016). Bibliometric Studies in Tourism. Annals of Tourism Research, 61, 180-198.

Kozak, M. A., Evren, S., \& Çakır, O. (2013). Tarihsel Süreç İçinde Turizm Paradigması. Anatolia: Turizm Araştırmaları Dergisi, 24(1), 7-22.

Kurtzman, J. (2005). Sports tourism categories. Journal of Sport Tourism, 10(1), 15-20.

López-Bonilla, L. M., Reyes-Rodríguez, M. D. C., \& López-Bonilla, J. M. (2020). Golf tourism and sustainability: Content analysis and directions for future research. Sustainability, 12(9), 3616.

Markwick, M. C. (2000). Golf Tourism Development, Stakeholders, Differing Discourses and Alternative Agendas: the Case of Malta. Tourism Management, 21(5), 515-524.

Maldonado-Erazo, C. P., \& Álvarez-García, J. (2018). State of the art of research in the sector of thermalism, thalassotherapy and spa: A bibliometric analysis. European Journal of Tourism Research, 19, 56-70.

Millington, R., Darnell, S. C., \& Millington, B. (2018). Ecological modernization and the Olympics: The case of golf and Rio’s “Green” games. Sociology of Sport Journal, 35(1), 8-16.

Niñerola, A., Sánchez-Rebull, M. V., \& Hernández-Lara, A. B. (2019). Tourism Research on Sustainability: A Bibliometric Analysis. Sustainability, 11(5), 1377.

Okumus, B., Koseoglu, M. A., \& Ma, F. (2018). Food and Gastronomy Research in Tourism and Hospitality: A Bibliometric Analysis. International Journal of Hospitality Management, 73, 64-74.

Petrosillo, I., Valente, D., Pasimeni, M. R., Aretano, R., Semeraro, T., \& Zurlini, G. (2019). Can a golf course support biodiversity and ecosystem services? The landscape context matter. Landscape Ecology, 1-16.

Pritchard, A. (1969). Statistical Bibliography or Bibliometrics. Journal of Documentation, 25(4), 348-349. 
Río-Rama, M., Maldonado-Erazo, C., Durán-Sánchez, A., \& Álvarez-García, J. (2019). Mountain tourism research. A review. European Journal of Tourism Research, 22, 130-150.

Ruhanen, L., Weiler, B., Moyle, B. D., \& McLennan, C. L. J. (2015). Trends and Patterns in Sustainable Tourism Research: A 25-year Bibliometric Analysis. Journal of Sustainable Tourism, 23(4), 517-535.

Salici, O., \& Özdaşl1, K. (2016). Türkiye Spor Turizminde Masa Tenisinin Yeri. Mehmet Akif Ersoy Üniversitesi İktisadi ve Ídari Bilimler Fakültesi Dergisi, 3(2), 36-46.

Sánchez, A. D., Del Río, M. D. L. C., \& García, J. Á. (2017). Bibliometric Analysis of Publications on Wine Tourism in the Databases Scopus and WoS. European Research on Management and Business Economics, 23(1), 8-15.

Sengupta, I. N. (1992). Bibliometrics, Informetrics, Scientometrics and Librametrics: An Overview. Libri, 42(2), $75-98$.

Soyak, M. (2013). Uluslararası turizmde son eğilimler ve Türkiye'de turizm politikalarının evrimi. Marmara Sosyal Araştırmalar Dergisi, 4, 1-18.

Tassiopoulos, D., \& Haydam, N. (2008). Golf Tourists In South Africa: A Demand-side Study of a Niche Market in Sports Tourism. Tourism Management, 29(5), 870-882.

Tregua, M., D’Auria, A. \& Costin, H. (2020). \#10yearschallenge: how co-creation permeated tourism research. A bibliometric analysis. European Journal of Tourism Research 24, 2409.

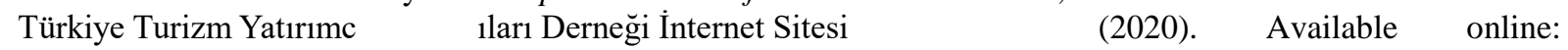
http://www.ttyd.org.tr/userfiles/GOLF\%20TURizMi\%20(3).doc (accessed on: 20 July 2020).

Van Eck, N., \& Waltman, L. (2010). Software Survey: VOSviewer, a Computer Program for Bibliometric Mapping. Scientometrics, 84(2), 523-538.

Yıldı, T., \& Aykanat, Z. (2015). Clustering and Innovation Concepts and Innovative Clusters: An Application on Technoparks in Turkey. Procedia-Social and Behavioral Sciences, 195, 1196-1205. 